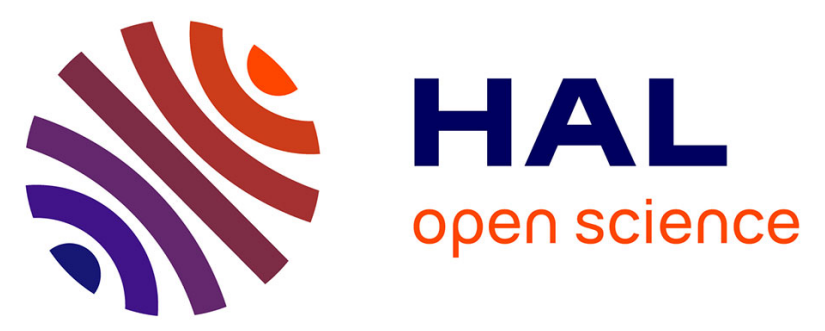

\title{
When everything converges: Integrative taxonomy with shell, DNA and venomic data reveals Conus conco, a new species of cone snails (Gastropoda: Conoidea)
}

Nicolas Puillandre, Reto Stöcklin, Philippe Favreau, Estelle Bianchi, Frédéric

Perret, Audrey Rivasseau, Loïc Limpalaër, Eric Monnier, Philippe Bouchet

\section{To cite this version:}

Nicolas Puillandre, Reto Stöcklin, Philippe Favreau, Estelle Bianchi, Frédéric Perret, et al.. When everything converges: Integrative taxonomy with shell, DNA and venomic data reveals Conus conco, a new species of cone snails (Gastropoda: Conoidea). Molecular Phylogenetics and Evolution, 2014, 80, pp.186-192. 10.1016/j.ympev.2014.06.024 . hal-02458200

\section{HAL Id: hal-02458200 \\ https://hal.science/hal-02458200}

Submitted on 28 Jan 2020

HAL is a multi-disciplinary open access archive for the deposit and dissemination of scientific research documents, whether they are published or not. The documents may come from teaching and research institutions in France or abroad, or from public or private research centers.
L'archive ouverte pluridisciplinaire HAL, est destinée au dépôt et à la diffusion de documents scientifiques de niveau recherche, publiés ou non, émanant des établissements d'enseignement et de recherche français ou étrangers, des laboratoires publics ou privés. 


\section{When everything converges: integrative taxonomy with shell, DNA and venomic data}

reveals Conus conco, a new species of cone snails (Gastropoda: Conoidea)

Puillandre Nicolas $^{\mathrm{a}, \mathrm{b}, *}$, Stöcklin Reto ${ }^{\mathrm{b}}$, Favreau Philippe ${ }^{\mathrm{b}}$, Bianchi Estelle ${ }^{\mathrm{b}}$, Perret Frédéric ${ }^{\mathrm{b}}$, Rivasseau Audrey ${ }^{\mathrm{c}}$, Limpalaër Loïc ${ }^{\mathrm{d}}$, Monnier Eric ${ }^{\mathrm{e}}$, Bouchet Philippe ${ }^{\mathrm{f}}$.

${ }^{\text {a }}$ Museum National d'Histoire Naturelle, Departement Systematique et Evolution, ISyEB Institut (UMR 7205 CNRS/UPMC/MNHN/EPHE), 43, Rue Cuvier, 75231 Paris, France

${ }^{\mathrm{b}}$ Atheris Laboratories, Case postale 314, CH-1233 Bernex-Geneva, Switzerland

' UMS 2700, Museum National d'Histoire Naturelle, Departement Systematique et Evolution, 43, Rue Cuvier, 75231 Paris, France

d 11, rue de la Poste 60510 Haudivillers

e Conservatoire National des Arts et Métiers, Département Chimie, Alimentation, Santé, Environnement et Risque, 292, rue Saint-Martin, 75003 Paris, France

${ }^{\mathrm{f}}$ Museum National d'Histoire Naturelle, Departement Systematique et Evolution, ISyEB Institut (UMR 7205 CNRS/UPMC/MNHN/EPHE), 55, Rue Buffon, 75231 Paris, France

* Corresponding author: Tel: +33 1407931 73; puillandre@mnhn.fr 


\section{Abstract}

Cone snails have long been studied both by taxonomists for the diversity of their shells and by biochemists for the potential therapeutic applications of their toxins. Phylogenetic approaches have revealed that different lineages of Conus evolved divergent venoms, a property that is exploited to enhance the discovery of new conotoxins, but is rarely used in taxonomy. Specimens belonging to the Indo-West Pacific Conus lividus species complex were analyzed using phenetic and phylogenetic methods based on shell morphology, COI and 28S rRNA gene sequences and venom mRNA expression and protein composition. All methods converged to reveal a new species, $C$. conco n. sp. (described in the supplementary data), restricted to the Marquesas Islands, where it diverged recently ( $\sim 3$ mya) from $C$. lividus. The geographical distribution of $C$. conco and $C$. lividus and their phylogenetic relationships suggest that the two species diverged in allopatry. Furthermore, the diversity of the transcript sequences and toxin molecular masses suggest that $C$. conco evolved unique toxins, presumably in response to new selective pressure, such as the availability of new preys and ecological niches. Furthermore, this new species evolved new transcripts giving rise to original toxin structures, probably each carrying specific biological activity.

Keywords: Conidae, Conopeptides, MALDI-TOF-MS, Mass spectrometry, RNA-Seq, Species delimitation, Toxins, Transcriptomes, Venom gland. 


\section{Introduction}

Far ahead of snakes and together with scorpions and spiders, cone snails are among the three most promising groups of venomous animals for pharmaceutical studies given the diversity of their toxins (King et al., 2008). Recent proteomic approaches reveal that each cone snail species may be able to produce at least 200 unique conotoxins or other proteins (Violette et al., 2012) and possibly even thousands if all variants and fragments are explored (Dutertre et al., 2013). Furthermore, as many as 761 species are now considered valid (www.marinespecies.org) and this number is expanding. This would lead to an estimate of at least 150,000 toxins, given that thousands of marine molluscs of the Conoidea superfamily remain to be investigated.

The diversity of the conotoxins, driven by either mechanisms such as recombination or gene duplication and positive selection (Duda, 2008), has been invoked for to explain the higher rates of diversification of cone snails compared to other predatory - but non venomous - neogastropods (Olivera, 2006). It has been shown that (i) even closely related species of cone snails may exhibit different feeding specializations (Kohn, 2001) and (ii) each cone species possesses its own arsenal of toxins, weakly overlapping with the arsenal of other species (Kaas et al., 2010; Olivera, 2006). Duda (2008) thus suggested that prey shifts after speciation induces a strong positive selection on venom, and the emergence of new toxins more adapted to the new prey, in line with the hypotheses proposed for snakes (Barlow et al., 2009) and scorpions (Kozminsky-Atias et al., 2008).

We present here an integrative approach, including morphological analysis, DNA sequencing and venom characterization that led to the recognition of a new species of cone snails in the Conus lividus complex, which we name Conus conco new species (description is provided in the Supplementary Data 1). Conus conco is restricted to the Marquesas Archipelago, where it had earlier been mistaken for $C$. sanguinolentus or $C$. lividus (Moolenbeek et al., 2008). We used phenetic approaches for morphological characters and phylogenetic methods for DNA sequences (COI and 28S genes) to distinguish this new species from other species that belong to the same complex ( $C$. diadema, $C$. sanguinolentus and C. lividus). A new approach is also proposed: the presence/absence of the different toxins detected by MALDI-TOF-MS analysis of the venom of multiple specimens from $C$. sanguinolentus, C. lividus and C. conco n. sp. can be coded in a matrix, similar to traditional analyses of morphological characters. Chemical signals, including toxins, have previously been used as characters to confirm an existing phylogeny, using classic phylogenetic approach or clustering methods (Nascimentoa et al., 2006), but rarely to help recognizing a new species. These data, together with venom gland transcriptome investigation, revealed that $C$. conco evolved specific conotoxins not found in its sister-species. The patterns of phylogenetic relationships, divergence estimation, geographical distribution and venom diversity, within and between species, are discussed to suggest a speciation scenario that led to the emergence of this new species of cone snail.

\section{Material and methods}

\subsection{Sampling}

Most specimens were collected during three expeditions in 2007 to Tahiti and the Marquesas and Chesterfield Islands. Specimens were photographed, the shell was broken and the animal was then directly dissected on site. A piece of foot tissue was preserved in ethanol, radular sacs were stored dry at $-80^{\circ} \mathrm{C}$. Extracts of the venom duct were dissolved in $10 \%$ acetic acid in water, dried under vacuum and stored at $-80^{\circ} \mathrm{C}$. The remaining venom gland was preserved in RNALater (Ambion) for further transcriptomic studies. Whenever possible, shells were reconstructed for use as vouchers. Additional comparative material originates from expeditions in the Philippines (Panglao 2004), Vanuatu (Santo 2006) and Madagascar (Atimo Vatae 2011). A piece of foot tissue was cut from the body and placed in $95 \%$ ethanol. All 
specimens were collected in shallow water (between 0 and 10 meters), and were identified in the field as C. lividus or C. sanguinolentus (following the taxonomy of Röckel et al., 1995, and referred to as Lividoconus in Tucker and Tenorio, 2013).

Outgroups for phylogenetic analyses were selected according to the last available classification of cone snails (Tucker and Tenorio, 2013) and on the available phylogenetic analyses for the group. Conus muriculatus was used as closely related outgroup. Other species of Conus (C. virgo, C. consors and C. marmoreus) were also used as outgroups. Conasprella pagoda (Conidae) and Bathytoma carnicolor (Conoidea, Borsoniidae) were used as distant outgroups. Finally, in the COI gene dataset, Conus quercinus was also added to date the species divergences (see 2.2).

\subsection{DNA sequencing and phylogenetic analyses}

DNA was extracted using the Epmotion 5075 robot (Eppendorf). Fragments of the COI and rDNA28S genes of 658 and $750 \mathrm{bp}$, respectively, were amplified using the protocol described in Kantor et al. (2013). PCR products were purified and sequenced by Eurofins in both directions. Available COI and $28 \mathrm{~S}$ sequences for $C$. lividus, $C$. diadema and $C$. sanguinolentus in GenBank were downloaded and added to the dataset. GenBank accession numbers are provided in the Supplementary Data 2.

Sequences were manually (COI gene) or automatically (28S gene) aligned using ClustalW multiple alignment (BioEdit 7.0.5.3, Hall, 1999). The best model of evolution was selected for each gene using Modelgenerator V.85 (Keane et al., 2006), following the Hierarchical Likelihood Ratio Tests (with four discrete gamma categories). The best substitution models are $\mathrm{TrN}+\mathrm{G}$ for both COI and 28S genes. Bayesian Analyses (BA) were performed including only one sequence per haplotype and running two parallel analyses in MrBayes (Huelsenbeck et al., 2001), consisting each of eight Markov chains of 10,000,000 generations. A GTR $+G$ model was applied to each gene. Tracer 1.4.1 (Rambaut and Drummond, 2007) was used to check that ESS values were all greater than to 200. A consensus tree was then calculated after omitting the first $25 \%$ trees as burn-in.

The divergences of the genus Conus from the other conoideans, and of C. quercinus from C. lividus, respectively estimated at 55 mya and 11 mya based on fossil records (Duda and Kohn, 2005), were used as calibration points to date the divergences between the different species included in the C. lividus complex. BEAST 1.8.0 (Drummond and Rambaut, 2007) was used to reconstruct a phylogenetic tree based on a concatenation of the COI and $28 \mathrm{~S}$ sequences including one specimen per species. The priors of the $t_{\text {MRCA }}$ of the cone snails and of the clade including $C$. quercinus, $C$. lividus, $C$. sanguinolentus and $C$. conco were set to follow a lognormal distribution. An uncorrelated lognormal relaxed clock with a "birth-death incomplete sampling" speciation model was applied and independent models of substitutions (TN93+G) were defined for each gene. Two MCMC chains were run for 100,000,000 generations. Convergence of the runs was tested as described previously. Tree annotator 1.8.0 (http://beast.bio.ed.ac.uk) was used to summarize the tree data generated by BEAST.

\subsection{Venom MALDI-TOF-MS fingerprinting}

MALDI-TOF-MS analyses were carried out on an Ultraflex TOF-TOF mass spectrometer operated in positive reflector mode $(\mathrm{m} / \mathrm{z} 480-5,000)$ under the control of the FlexControl 2.2 software (Bruker, Bremen, Germany). Samples (listed in the Supplementary Data 2) were deposited on a 384 AnchorChip 600 plate using an affinity method based on manufacturer's guide to sample preparation. External calibration was carried out and checked in the 700 3,500 Da mass range with an error 50 ppm.

The FlexAnalysis 2.2 software (Bruker) was used for data processing and analysis. Only the best representative mass spectrum of each venom was selected for data 
interpretation, i.e. the one with the highest number of signals and the best signal-to-noise ratio.

Each ionized molecular species obtained in the 41 mass spectra was considered as a different character with two different states, present (1) or absent (0). A total of 444 characters were coded, and the matrix obtained was analyzed using MrBayes (Huelsenbeck et al., 2001). Two parallel analyses were performed, each consisting of eight Markov chains of 10,000,000 generations. Convergence of the runs was tested as described previously. A consensus tree was calculated after omitting the first $25 \%$ trees as burn-in. The absence of outgroup in this analysis is due to the unavailability of venom for closely related species, and to the fact that venom available for more distant species had almost no mass in common with the three species of the lividus complex.

\subsection{Venom gland mRNA transcriptomic sequencing}

Six venom glands (two per species) were used for transcriptomic analyses (specimens listed in the Supplementary Data 2). Total RNA was extracted from the glands using a TissueLyzer LT (Qiagen) and the method developed by Chomczynski (1993). Messenger RNA was purified using the Dynabeads mRNA purification kit (Invitrogen) and the quality of total and mRNA was verified using a 2100 Bioanalyzer (Agilent technologies). The construction of the whole transcriptome libraries, the sample preparation for RNA-Seq sequencing and the sequencing were performed according to the Ion Torrent protocols using the Ion Torrent Personal Genome Machine (PGM).

Reads obtained from the Torrent Suite Software (version 3.6) were converted to FastQ format for subsequent data analysis. Sequencing quality was assessed by aligning the reads to housekeeping genes of Gastropods (CEGMA database and NCBI BLAST version 2.2.26). Data belonging to rRNA and identical sequences were removed by matching reads against public rRNA sequences (Silva database and NCBI BLAST version 2.2.26) followed by clustering together reads of $100 \%$ identity (CD-HIT-454 version 4.5.4). De novo assembly was performed using MIRA (version 3.9.15) with default parameters for Ion Torrent data. Contigs represented by less than 10 reads were discarded. Sequences coding for toxins were detected using GeneWise (EMBL-EBI version 2.4.1 - (Birney et al., 2004)) and HMMER2 models based on public sequences of conotoxins (ConoServer and UniProt). Signal sequences in toxins were identified using an in-house (Koua et al., 2013).

\section{Results}

\subsection{Morphological analyses}

The specimens collected in the Marquesas Islands, and preliminarily identified as $C$. sanguinolentus, formed two morphologically separable clusters (Fig 1). One morphotype, with an average total shell length of $48 \mathrm{~mm}$, is characterized by a lavender to purple background color; the other morphotype, with an average total shell length of $35 \mathrm{~mm}$, is olive or yellowish brown and lacks the lavender to purple background color (the Supplementary Data 1). The larger morphotype was only found in the Marquesas Islands, where it seemed to replace $C$. lividus, which is found throughout the Indo-Pacific except in the Marquesas. This purple morphotype likely represent a new species (and this hypothesis is supported by other evidence - see below), and it is described as Conus conco new species (the Supplementary Data 1).

\subsection{Phylogenetic analyses}

Analyses of the COI and 28S genes resulted in phylogenetic trees with identical topology (Fig. 2). Specimens identified as C. lividus all belonged to a single clade (Posterior Probability PP $=0.88$ for the COI, 0.98 for the 28S). Similarly, the two COI sequences of $C$. diadema from GenBank clustered in a highly supported clade $(\mathrm{PP}=1)$. However, specimens 
identified as $C$. sanguinolentus clustered in two different clades (each with PP $=1$ ). One of them included only specimens now identified as C. conco n. sp., and was the sister-group of C. lividus. These four clades were all grouped in a single clade ( $\mathrm{PP}=1$ for COI and 28S), sister-group of $C$. quercinus.

Using two calibration points, the ages of the clade including $C$. sanguinolentus, $C$. lividus and C. conco (C. diadema was not included in this analysis, because no $28 \mathrm{~S}$ sequence was available for it) and the clade including $C$. lividus and $C$. conco were estimated at 7.84 mya (5.12-12.46) and 2.738 mya (1.11-4.73) respectively (Fig. 3)

\section{$\underline{3.3 \text { Toxin MS profile and venom gland RNA-Seq transcriptomes }}$}

A total of 444 monoisotopic signals (consisting of a single isotope) could be detected from the 41 venoms of $C$. lividus, $C$. sanguinolentus and $C$. conco in the mass range $m / z \quad 480-5,000$ corresponding to the molecular masses of most known conopeptides (Conoserver; Kaas et al., 2010). Each signal was generally found in only a few specimens (mean $=3.27$ ) reflecting a high level of intra-specific venom variation, and only 30 were found in more than 10 specimens. Each specimen of C. lividus, C. sanguinolentus and C. conco included a mean of 35.6, 31.5 and 37.19 different conotoxin masses, respectively. Eleven signals (given in Da) found in at least $50 \%$ of the $C$. conco specimens, but never in C. lividus or C. sanguinolentus were identified: 1053 (found in 17 specimens of C. conco), 1077 (12), 1585 (17), 1615 (18), 1754 (17), 1772 (13), 1812 (12), 1932.8 (14), 1970 (14), 2299 (16), 2321 (12). The phylogenetic analysis of the 41 mass spectra resulted in a tree with three main groups, each including only specimens from the same species (Fig. 4).

The sequencing of these Conus venom glands libraries yielded around 2 million reads that were then assembled into 100,000 contigs on average. Transcriptome analyses confirmed the high diversity of toxins found in the three species. In total, 88 different toxin precursors were found in the six specimens analyzed, attributable to 12 different superfamilies using the signal sequences (following the classification in Puillandre et al., 2012), plus one set of 8 sequences (found in the three species) characterized by a signal sequence different from the known superfamily of conotoxins (Supplementary Data 3). Most precursor amino-acid sequences are unique to a single species, but three are shared by the three species, four by $C$. lividus and C. sanguinolentus and nine by $C$. conco and $C$. lividus, in agreement with the fact that $C$. conco and $C$. lividus are closely related and diverged from each other more recently than from C. sanguinolentus. Correlating the MALDI-TOF-MS signals and the transcriptome data to infer potential mature conotoxin sequences was judged to be too hypothetical due to the elevated number of matches resulting from unknown precursor cleavages sites, undefined post-translational modifications and the lack of any previously characterized toxins from these species.

\section{Discussion}

Congruence of the phylogenetic trees resulting from the two unlinked markers (COI, mitochondrial, and 28S, nuclear) is a strong, although indirect, evidence for reproductive isolation among $C$. sanguinolentus, $C$. lividus and $C$. conco. Moreover, they are characterized by highly divergent sets of toxins and different shell characters. All these evidences strongly support that $C$. lividus and $C$. conco are isolated species - and not divergent populations within a single species that would be still able to exchange genes - and this justifies the description of $C$. conco as a new species.

To understand how $C$. conco diverged from $C$. lividus, several patterns must be taken into account. First, the geographical distributions of the two species are clearly allopatric. Conus lividus is present in all the Indo-West Pacific except in the Marquesas Islands, and our analyses show that specimens from the two extremes of the range (Madagascar and Tahiti) are genetically indistinguishable (Fig 2). Conversely, C. conco is known only from the Marquesas 
Islands. Second, phylogenetic analyses show that C. conco and C. lividus are sister groups. Third, C. conco and C. lividus diverged recently ( 2.738 mya), i.e. between 2 and 6 my after the elevation of the first island of the Marquesas above sea level (Eiao Island is estimated to have emerged between 4.99 and 8.72 mya - Clouard and Bonneville, 2005). Fourth, C. conco expressed specific precursor sequences and toxin molecular masses not found in C. lividus and C. sanguinolentus (Fig. 4). In particular, 11 toxin masses are present in most C. conco specimens and not in the other two species, suggesting that this is not just a sampling bias. Finally, the protoconchs of all C. conco specimens were eroded, but that of its sister species C. lividus is multispiral (four whorls - (Röckel et al., 1995)), suggesting a high dispersal potential (Jablonski and Lutz, 1980).

Given the geographic distribution of $C$. conco and $C$. lividus and the fact that the speciation event occurred after the emergence of the Marquesas archipelago, it is more likely that the speciation process occurred in the Marquesas Islands. If the speciation process that led to the emergence of $C$. conco and C. lividus has occurred in sympatry, e.g. as a result of a prey shift, then the two species diverged after the colonization of the Marquesas Islands by $C$. lividus. This hypothesis is supported by the differentiation of the toxin repertoire in C. conco (thus linked to the prey shift). Conus lividus is known to prey on polychaetes (direct observations, Kohn, 1959), a taxonomically and ecologically very diversified group, and it is probable that the guild of polychaete species found in the Marquesas differs significantly from that occurring elsewhere in French Polynesia or the Indo-West Pacific. However, the sympatric hypothesis does not explain the current geographical distribution. If $C$. conco and C. lividus are now adapted to different habitats (i.e. different preys), they are no longer competitors (Quenouille et al., 2011) and there is no simple explanation why C. lividus is absent from the Marquesas Islands. Alternatively, the divergence may also be the result of a peripatric speciation event, where a small peripheral population of $C$. lividus colonized the Marquesas Islands, in agreement with the geographic distribution of the two species. However, and following the peripatric hypothesis, the differentiation of the toxin repertoire in C. conco would be more difficult to explain. Duda \& Lee (2009) suggested that ecological release, occurring when an isolated population is under relaxed selective pressure (e.g. predator-prey arm race relaxed), led to the appearance of new toxins, even without prey shift, in $C$. miliaris. This hypothesis may apply to $C$. conco. The absence of C. lividus in the Marquesas Islands, although present in close archipelagos, would be explained by competitive exclusion.

Demonstrating ecological speciation and identifying the underlying mechanisms require methods that are difficult to apply to cone snails. Characterizing the prey of $C$. conco and $C$. lividus would be a first step forward, either by direct observation or by analysis of the gut contents. Furthermore, several questions linked to ecological speciation in cone snails remain unanswered. How can two sympatric populations diverge when larvae are highly dispersive? Existing hypotheses relate to the partition in microhabitats that would prevent adults from meeting and maladapted larvae to settle (Krug, 2011). Then, what is the exact role of the toxins in the prey shift? Conticello et al. (2001) suggested that non expressed toxins present in the genomes can serve as a reservoir in prevision of the appearance of a new prey ("lazarotoxins"), but the new toxins may also appear after the prey shift to increase the specificity of the venom. Clearly, a model-based approach is required in order to better characterize the genetic diversity, biology and ecology of the two species.

\section{Acknowledgments}

We are grateful to Felix Lorenz (Buseck-Beuern) who first noticed that the "Conus lividus" from the Marquesas was "something different", and generously handed it over for us to name it in the context of this integrative approach. This project is part of CONCO, the cone snail genome project for health, funded by the European Commission: LIFESCIHEALTH-6 
Integrated Project LSHB-CT-2007-037592 and we are grateful to Dr Torbjörn Ingemansson, scientific officer. The CONPOL 2007 CONCO expedition to French Polynesia (Nuku Hiva in the Marquesas, Tahiti and Takapoto) was co-organised by Atheris Laboratories (Geneva, Switzerland) and the Institut Français de Recherche pour l'Exploitation de la Mer (IFREMER) in partnership with the Institut de Recherche pour le Développement (IRD). The CONFIELDI 2007 CONCO expedition to the Chesterfield Islands (New Caledonia) was co-organised by Atheris Laboratories (Geneva, Switzerland) and the IRD in partnership with the French Navy (vaisseau P400 “La Glorieuse”). The PANGLAO 2004 Marine Biodiversity Project was funded by the Total Foundation and the French Ministry of Foreign Affairs. The MNHNIRD-PNI Santo 2006 (Vanuatu) and Atimo Vatae 2010 (Madagascar) expeditions was made possible by grants, among others, from the Total Foundation, the Stavros Niarchos Foundation, and the Prince Albert II of Monaco Foundation. This project was partly supported by the network "Bibliothèque du Vivant" funded by the CNRS, the Muséum National d'Histoire Naturelle, the INRA and the CEA (Genoscope) and by the "Service de Systématique Moléculaire" (UMS 2700 CNRS-MNHN) and by the project CONOTAX, funded by the French "Agence Nationale de la Recherche" (grant number ANR-13-JSV70013-01). We would like to thank Evelyne Bachère, Michel Balleton, Philippe Favreau, Antoine Gilbert, Peva Levy, David Piquemal, Joël Orempuller, Piapao and Reto Stöcklin, who collected the specimens of $C$. conco in the Marquesas Archipelago, Napoleon Colombani, Alain Gerbault, Jean-Louis Menou, Robin Offord, and Reto Stöcklin who collected samples in the Chesterfield Islands, Sébastien Dutertre and Oliver Cheneval for the preparation of the samples, Roman Mylonas and Florence Bandelier (Atheris Laboratories) for the transcriptomic analyses, and Manuel Tenorio who prepared and photographed the $C$. conco n. sp. radula. Last but not least, we express our gratitude to Jacques Pusset (Toxinomics Foundation), Claude Payri (IRD) and the governments of French Polynesia and New Caledonia.

\section{References}

Barlow, A., Pook, C.E., Harrison, R.A., Wüster, W., 2009. Coevolution of diet and preyspecific venom activity supports the role of selection in snake venom evolution. Proc. R. Soc. B Biol. Sci. 276, 2443-2449.

Birney, E., Clamp, M., Durbin, R., 2004. GeneWise and genomewise. Genome Res. 14.5, 988-995.

Chomczynski, P., 1993. A reagent for the single-step simultaneous isolation of RNA, DNA and proteins form cell and tissue samples. BioTechniques 15, 532-537.

Clouard, V., Bonneville, A., 2005. Ages of seamounts, islands and plateaus on the Pacific plate, in: Foulger, G.R., Natland, J.H., Presnall, D.C., Anderson, D.L. (Eds.), Plates, Plumes, and Paradigms. Geological Society of America, Boulder, USA, pp. 71-90.

Conticello, S.G., Gilad, Y., Avidan, N., Ben-Asher, E., Levy, Z., Fainzilber, M., 2001. Mechanisms for evolving hypervariability: the case of conopeptides. Mol. Biol. Evol. 18, 120-131.

Drummond, A.J., Rambaut, A., 2007. BEAST: Bayesian evolutionary analysis by sampling trees. BMC Evol. Biol. 7, 214.

Duda, T.F.J., 2008. Differentiation of venoms of predatory marine gastropods: divergence of orthologous toxin genes of closely related Conus species with different dietary specializations. J. Mol. Evol. 67, 315-321.

Duda, T.F.J., Kohn, A.J., 2005. Species-level phylogeography and evolutionary history of the hyperdiverse marine gastropod genus Conus. Mol. Phylogenet. Evol. 34, 257-272.

Duda, T.F.J., Lee, T., 2009. Ecological release and venom evolution of a predatory marine Snail at Easter Island. PLoS ONE 4, e5558. 
Dutertre, S., Jin, A.H., Kaas, Q., Jones, A., Alewood, P.F., Lewis, R.J., 2013. Deep venomics reveals the mechanism for expanded peptide diversity in cone snail venom. Mol. Cell. Proteomics 12, 312-329.

Hall, T.A., 1999. BioEdit: a user-friendly biological sequence alignment editor and analysis program for Windows 95/98/NT. Nucleic Acids Symp. Ser. 41, 95-98.

Huelsenbeck, J.P., Ronquist, F., Hall, B., 2001. MrBayes: Bayesian inference of phylogeny. Bioinformatics 17, 754-755.

Jablonski, D., Lutz, R.A., 1980. Molluscan larval shell morphology - ecological and paleontological applications, in: Rhoads, D.C., Lutz, R.A. (Eds.), Skeletal Growth of Aquatic Organisms. Plenum Press, New York, pp. 323-377.

Kaas, Q., Westermann, J.C., Craik, D.J., 2010. Conopeptide characterization and classifications: An analysis using ConoServer. Toxicon 55, 1491-1509.

Kantor, Y.I., Puillandre, N., Fraussen, K., Fedosov, A.E., Bouchet, P., 2013. Deep-water Buccinidae (Gastropoda: Neogastropoda) from sunken wood, vents and seeps: Molecular phylogeny and taxonomy. J. Mar. Biol. Assoc. U. K. 93, 2177-2195.

Keane, T.M., Creevey, C.J., Pentony, M.M., Naughton, T.J., McInerney, J.O., 2006. Assessment of methods for amino acid matrix selection and their use on empirical data shows that ad hoc assumptions for choice of matrix are not justified. BMC Evol. Biol. 6, 1-17.

King, G.F., Gentz, M.C., Escoubas, P., Nicholson, G.M., 2008. A rational nomenclature for naming peptide toxins from spiders and other venomous animals. Toxicon 52, 264276.

Kohn, A.J., 1959. The ecology of Conus in Hawaii. Ecol. Monogr. 29, 47-90.

Kohn, A.J., 2001. Maximal species richness in Conus: diversity, diet and habitat on reefs of northeast Papua New Guinea. Coral Reefs 20, 25-38.

Koua, D., Laht, S., Kaplinski, L., Stöcklin, R., Remm, M., Favreau, P., Lisacek, F., 2013. Position-specific scoring matrix and hidden Markov model complement each other for the prediction of conopeptide superfamilies. Biochim. Biophys. Acta BBA - Proteins Proteomics 1834, 717-724. doi:10.1016/j.bbapap.2012.12.015

Kozminsky-Atias, A., Bar-Shalom, A., Mishmar, D., Zilberberg, N., 2008. Assembling an arsenal, the scorpion way. BMC Evol. Biol. 8, 333.

Krug, P.J., 2011. Patterns of speciation in marine gastropods: A review of the phylogenetic evidence for localized radiations in the sea. Am. Malacol. Bull. 29, 169-186.

Moolenbeek, R.G., Zandbergen, A., Bouchet, P., 2008. Conus (Gastropoda,Conidae) from the Marquesas Archipelago: description of a new endemic offshore fauna. Vita Malacol. 6, 19-34.

Nascimentoa, D.G., Ratesa, B., Santosa, D.M., Verano-Bragaa, T., Barbosa-Silva, A., Dutra, A.A.A., Biondi, I., Martin-Eauclaire, M.F., De Lima, M.E., Adriano, M.C., 2006. Moving pieces in a taxonomic puzzle: Venom 2D-LC/MS and data clustering analyses to infer phylogenetic relationships in some scorpions from the Buthidae family (Scorpiones). Toxicon 47, 628-639.

Olivera, B.M., 2006. Conus peptides: biodiversity-based discovery and exogenomics. J. Biol. Chem. 281, 31173-31177.

Puillandre, N., Koua, D., Favreau, P., Olivera, B.M., Stöcklin, R., 2012. Molecular phylogeny, classification and evolution of conopeptides. J. Mol. Evol. 74, 297-309.

Quenouille, B., Hubert, N., Bermingham, E., Planes, S., 2011. Speciation in tropical seas: Allopatry followed by range change. Mol. Phylogenet. Evol. 58, 546-552.

Rambaut, A., Drummond, A.J., 2007. Tracer v1.4. Available from http://beast.bio.ed.ac.uk/Tracer.

Röckel, D., Korn, W., Kohn, A.J., 1995. Manual of the Living Conidae. Vol. I, Indo-Pacific. Christa Hemmen Verlag, Wiesbaden. 
Tucker, J.K., Tenorio, M.J., 2013. Illustrated catalog of the living cone shells. MDM Publishing, Wellington, USA.

Violette, A., Biass, D., Dutertre, S., Koua, D., Piquemal, D., Pierrat, F., Stöcklin, R., Favreau, P., 2012. Large-scale discovery of conopeptides and conoproteins in the injectable venom of a fish-hunting cone snail using a combined proteomic and transcriptomic approach. J. Proteomics 75, 5215-5225. 


\section{Figure caption}

Figure 1: Illustrations of shell and radula morphology. A-C: Conus conco n. sp., holotype MNHN 23355; D-E: Conus conco n. sp. radula (scale $=1 \mathrm{~mm}$ and $100 \mu \mathrm{m}$ respectively). F: Conus conco n. sp., paratype 7. G: Conus conco n. sp., paratype 8. H: Conus conco n. sp., paratype 9. I: Conus lividus, MNHN IM-2007-30891, Santo, Vanuatu. J: Conus lividus, 39.8 mm, Ile Ste Marie, Madagascar, coll. Monnier. K: Conus sanguinolentus, $42.2 \mathrm{~mm}$, Ile Ste Marie, Madagascar, coll. Monnier. L: Conus sanguinolentus, 52.8 mm, Taiohae, Nuku Hiva, coll. Monnier.

Figure 2: Bayesian phylogenetic trees (MrBayes) based on (A) the COI gene and (B) the 28S gene. Labels of the specimens correspond to the sample_ID in the the Supplementary Data 2 (GB = GenBank). PP (> 0.80) are indicated for each node. Geographic distribution (when known) is indicated as vertical bars: $\mathrm{C}=$ Chesterfield Islands; $\mathrm{Mg}=$ Madagascar; $\mathrm{Mq}=$ Marquesas Islands; $\mathrm{P}=$ Philippines; $\mathrm{SA}=$ South Africa, $\mathrm{T}=$ Tahiti; $\mathrm{V}=$ Vanuatu. (C): map showing the different sampling localities in the Indo-West Pacific.

Figure 3: Bayesian phylogenetic tree (BEAST) based on a concatenation of the COI and 28S genes with estimate of the age of each node (with confidence interval). PP ( $>0.95)$ are indicated for each node.

Figure 4: Phylogenetic tree obtained by coding the presence/absence of each toxin mass for the three species C. sanguinolentus (light grey lines), C. lividus (dark grey lines) and C. conco (black lines). 


\section{Suplementary Data}

Supplementary Data 1: Description of Conus conco new species

Supplementary Data 2: List of analyzed specimens. Sample ID (museum voucher ID when available), species name, locality, COI and 28S GenBank accession numbers. Specimens used for MALDI-TOF and transcriptomic analyses are marked with an " $x$ ” in the last two columns.

Supplementary Data 3: Conotoxin sequences found in the transcriptomes of C. lividus, $C$. sanguinolentus and C. conco.

Supplementary Data 4: Description of type specimens. Measurements are in millimeters, rounded to nearest $0.1 \mathrm{~mm}$. Measurements are made according to the method of Röckel et al.(1995). L: shell length; RD: relative diameter; MD: maximum diameter; PMD: position of maximum diameter; HMD: height of maximum diameter; RSH: relative spire height; $\mathrm{AH}$ : aperture height. A: Conus conco; B. Conus sanguinolentus; C. Conus lividus.

Supplementary Data 5: Maximum diameter (MD) plotted against Aperture height (AH) for $C$. lividus ( $\mathrm{n}=16$; diamonds), C. sanguinolentus ( $\mathrm{n}=15$; squares) and $C$. conco $(\mathrm{n}=17$; triangles). 

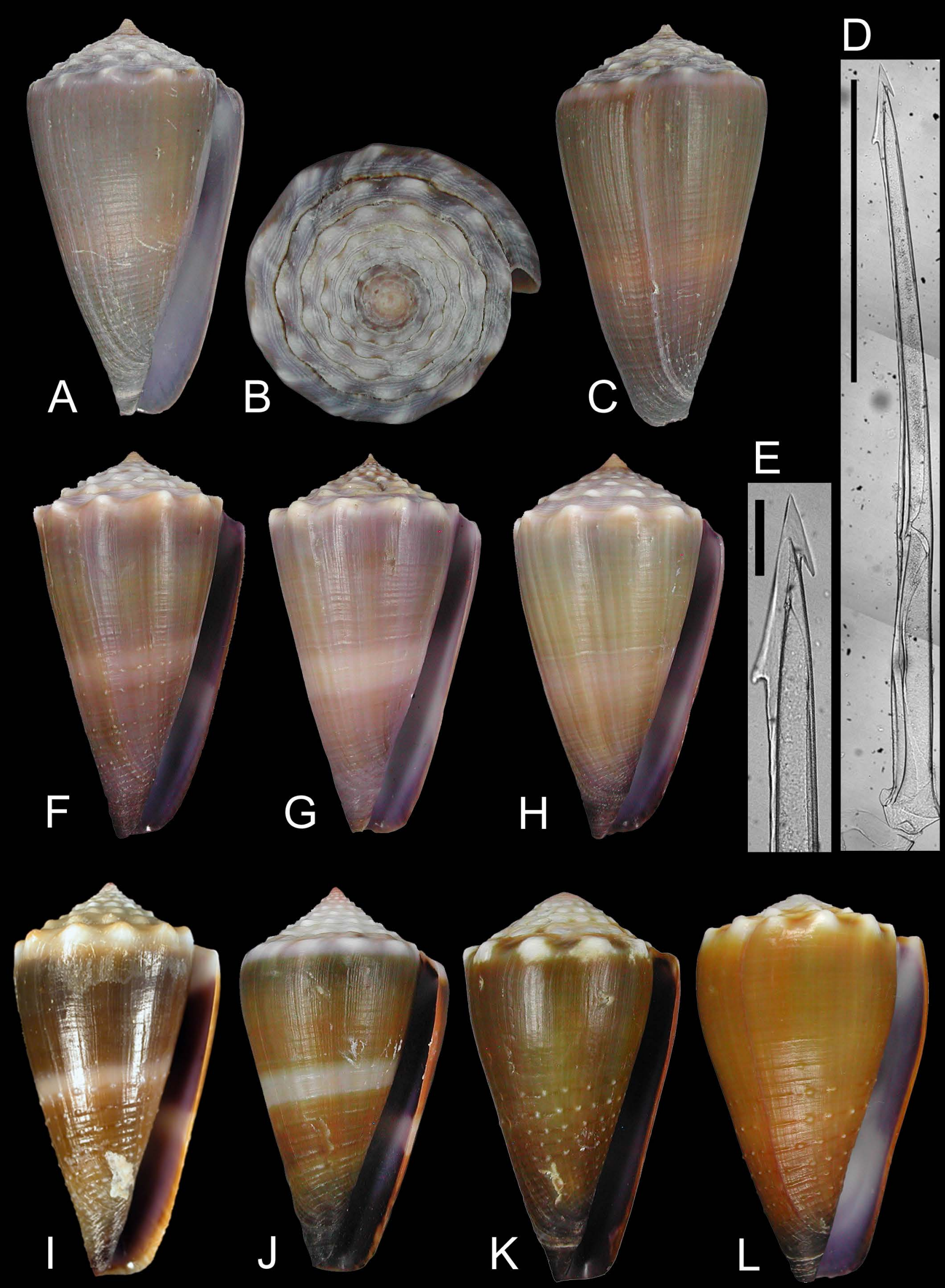


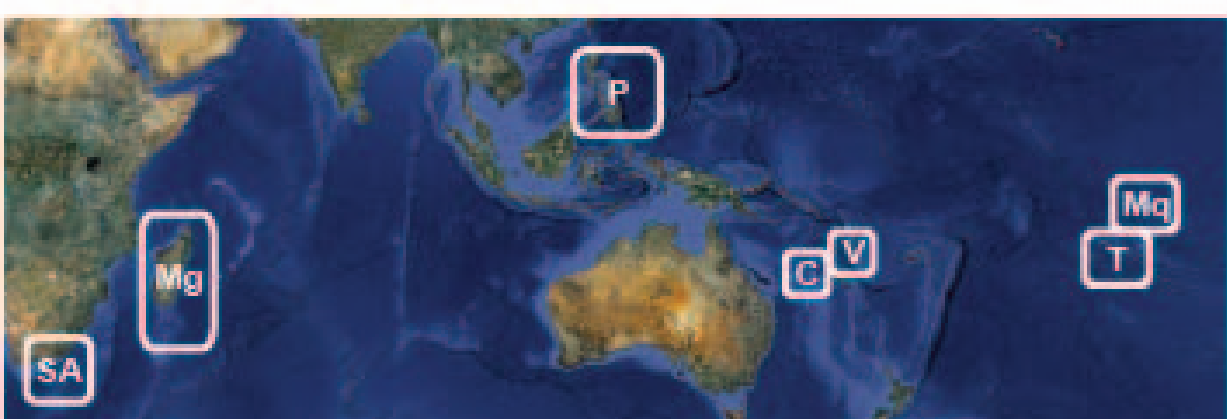




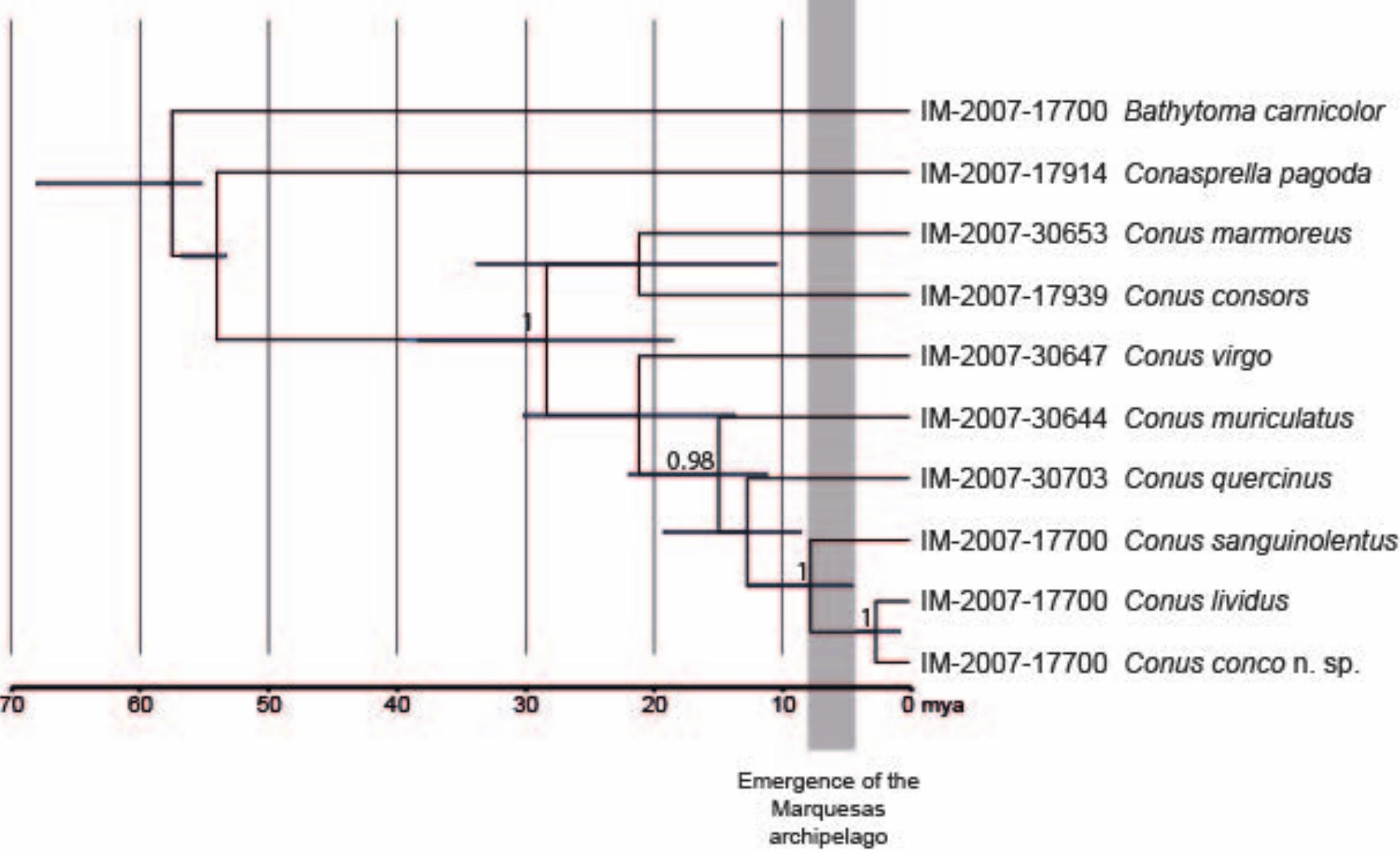




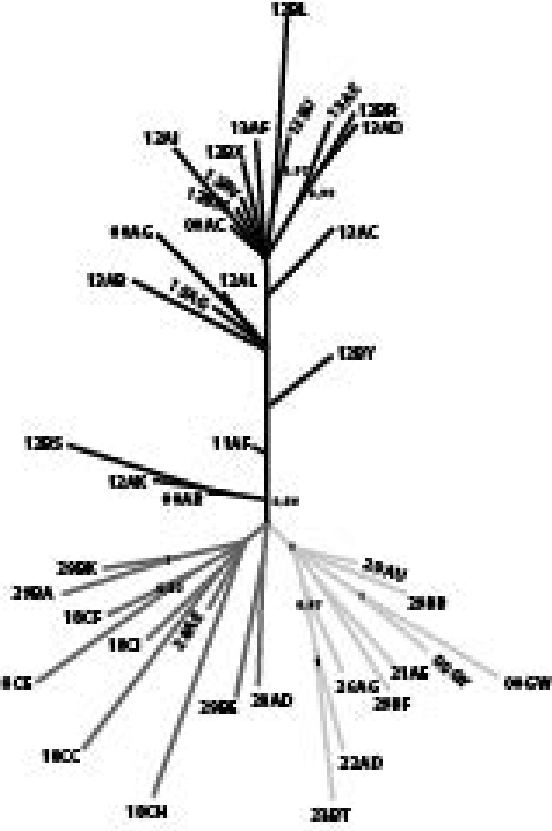


Corrigendum

Corrigendum to 'When everything converges: Integrative taxonomy with shell, DNA and venomic data reveals Conus conco, a new species of cone snails (Gastropoda: Conoidea)' [Molecular Phylogenetic and Evolution Vol. 80 (2014) 186-192]

Puillandre Nicolas ${ }^{\mathrm{a}, \mathrm{b}}$, Stöcklin Reto ${ }^{\mathrm{b}}$, Favreau Philippe ${ }^{\mathrm{b}}$, Bianchi Estelle $^{\mathrm{b}}$, Perret Frédéric ${ }^{\mathrm{b}}$, Rivasseau Audrey ${ }^{\mathrm{c}}$, Limpalaër Loïc ${ }^{\mathrm{d}}$, Monnier Eric ${ }^{\mathrm{e}}$, Bouchet Philippe ${ }^{\mathrm{f}}$.

${ }^{a}$ Museum National d'Histoire Naturelle, Departement Systematique et Evolution, ISyEB Institut (UMR 7205 CNRS/UPMC/MNHN/EPHE), 43, Rue Cuvier, 75231 Paris, France

${ }^{\mathrm{b}}$ Atheris Laboratories, Case postale 314, CH-1233 BernexGeneva, Switzerland

c UMS 2700, Museum National d'Histoire Naturelle, Departement Systematique et Evolution, 43, Rue Cuvier, 75231 Paris, France

d 11, rue de la Poste 60510 Haudivillers

${ }^{\text {e }}$ Conservatoire National des Arts et Métiers, Département Chimie, Alimentation, Santé, Environnement et Risque, 292, rue Saint-Martin, 75003 Paris, France

f Museum National d'Histoire Naturelle, Departement Systematique et Evolution, ISyEB Institut (UMR 7205 CNRS/UPMC/MNHN/EPHE), 55, Rue Buffon, 75231 Paris, France 
The article by Puillandre et al. (2014) included the description of the new species Conus conco. The formal description appeared in the online Supplementary Material only, and was not included in the printed version of the article. This description does not meet the requirements of the International Code of Zoological Nomenclature (ICZN) for electronic publications, and the name Conus conco Puillandre et al., 2014, is not a nomenclaturally available name.

To meet the ICZN requirements and make the name Conus conco available, the description (formerly Supplementary Material) is now published as a standard part of Molecular Phylogenetics and Evolution. The date of publication of the new species will be the date of publication of the printed edition of the journal.

\section{Description of Conus conco new species}

\section{Conus conco new species}

Type data: Holotype MNHN IM-2000-23355 (specimen Atheris MA071111AF) in Muséum National d'Histoire Naturelle, collected by Atheris Laboratories, under Reto Stöcklin (Fig. A1 A-C). Associated COI and 28S sequences deposited in GenBank under accession numbers KJ550027 and KJ603257, respectively.

Paratypes: 16 specimens (Puillandre et al., 2014, Supplementary data 4, Fig. A1 F-G). Type locality: Taioha'e bay, Nuku Hiva, Marquesas Islands, French Polynesia.

Etymology: The specific name is a noun in apposition. It is taken from the "Conco" European project.

Description: Shell of medium size, ranging from $37.4 \mathrm{~mm}$ to $56.8 \mathrm{~mm}$. Shape of the last whorl conical, constant in PMD (average 0.958) and RD (average 0.625). Spire low, with strongly tuberculated shoulder. Average RSH is 0.118 . Number of tubercles on the last whorl varies from 10 to 11 . Protoconch eroded in all studied specimens and number of its whorls unknown; deep pink in color from observation of the best preserved ones. Adult shell with 11 - 12 teleoconch whorls. Spire outline straight with pointed apex. Sutural ramp shows up to six irregular shallow spiral striae. Last whorl profile very slightly convex in the upper part of the last whorl and straight below.

Aperture slightly widening abapically. Holotype shell smooth on the adapical half of the last whorl and sculptured by narrow widely separated cords on the abapical part. In some specimens shell almost completely smooth, in others cords may be granulose. Shell color barely variable. Spire lavender to purple. First teleoconch whorls may have brown dots between the tubercles. Last whorl with lavender to mauve ground color overlaid with a plain beige coat missing in a wide, diffuse, mid-body and at periphery. Anterior extremity darker than the rest of the body whorl. Aperture deep violet or blue becoming lighter towards the interior and with a paler band in the middle. Periostracum golden brown, smooth and translucent. The radula (Fig. A1 D, E) shows no difference with the radula of C. lividus (Tucker and Tenorio, 2013).

Geographical range and habitat: Beside Nuku Hiva, Conus conco has also been collected in Ua Pou, Tahuata (this paper), and Ua Huka (Moolenbeek et al., 2008, as C. lividus), and appears to be endemic to the Marquesas archipelago. It has been collected under stones in 8 meters in Tahuata and in crevices between 15 and $30 \mathrm{~m}$ in Nuku Hiva (Alain Gaspard, pers. comm.). 
Remarks: Conus conco belongs to the Conus lividus (Hwass, 1792) species complex together with $C$. sanguinolentus (Quoy \& Gaimard, 1834) (Fig. A1 I-L). The three species cannot be separated based on their overall contours (Puillandre et al., 2014, Supplementary Material 5), and the only significant morphometric parameter that separates them is the adult size: $C$. sanguinolentus has the smallest shells (average size of $35.2 \mathrm{~mm}$, sample range from $24.9 \mathrm{~mm}$ to $44.9 \mathrm{~mm}$ ); C. lividus shells reach 73 mm (in our sample) and even $81 \mathrm{~mm}$ (Röckel et al., 1995) (minimum $=28.2 \mathrm{~mm}$ and average $=44.9 \mathrm{~mm}$ ); our sample of $C$. conco is quite homogeneous with an average size of $48 \mathrm{~mm}$, a minimum of $37.4 \mathrm{~mm}$ and a maximum of $56.8 \mathrm{~mm}$ (one specimen illustrated by Röckel et al. (1995), plate 4 fig. 12, reaches $61 \mathrm{~mm}$ ). Conus lividus differs from C. conco by its colour. The former is olive or yellowish brown; the spire and shoulder are completely white. No shell of C. lividus shows lavender to purple background color. Conus sanguinolentus, which is sympatric with the new species in the Marquesas, has brown spots between the spire tubercles but it never has a lavender to purple background color; pustules are more frequently present on the abapical cords.

Conus conco has been known for long and confused with C. sanguinolentus (Röckel et al., 1995) or C. lividus (Moolenbeek et al., 2008). It is also sometimes available in the specimens shell trade under the name Conus unicolor G.B. Sowerby I, 1833. The latter was named without description and type locality, no type specimen exists, and the type figure cannot be unambiguously recognized. Kohn (1992) concluded that it is a nomen dubium, an opinion followed by Filmer (2001). A different opinion was expressed by Richard (1985), who found similarities between the type figure of $C$. unicolor and shells originating from the Marquesas that are generally assigned to $C$. moreleti Crosse, 1858. Our opinion is that the type figure does not agree neither with C. conco nor with $C$. moreleti which has crowded nodules on the spire. Furthermore, no marine mollusc endemic to the Marquesas seems to have reached European conchologists until the early mid-1840s (Tröndle and Cosel, 2005). The voyage of the "Sulphur", which called in Nuku Hiva in January 1840, was the first British source that sampled the Marquesas. Thus Sowerby could not have Marquesan shells before that date.

Conus sanguinolentus Quoy \& Gaimard, 1834 was established based on the soft parts of a young specimen collected in Carteret [today Kavieng, New Ireland, Papua New Guinea]. This shell is not present in MNHN (where the Quoy and Gaimard material is preserved); Kohn (1992) designated the specimen illustrated by Quoy and Gaimard (1833, pl. 53 fig. 18) as the lectotype, and treated C.sanguinolentus as a valid species. By contrast, Richard (1985) considered C. sanguinolentus a synonym of C. lividus. Conus lividus Hwass, 1792 is defined by the lectotype in MHNG, and none of its accepted synonyms (Röckel et al., 1995) is applicable to the new species.

\section{References}

Filmer, R.M., 2001. A Catalogue of Nomenclature and Taxonomy in the Living Conidae 1758-1998. Backhuys Publishers, Leiden.

Kohn, A.J., 1992. A chronological taxonomy of Conus, 1758-1840. Smithsonian Institution Press, Washington.

Moolenbeek, R.G., Zandbergen, A., Bouchet, P., 2008. Conus (Gastropoda,Conidae) from the Marquesas Archipelago: description of a new endemic offshore fauna. Vita Malacol. 6, 19-34.

Puillandre, N., Stöcklin, R., Favreau, P., Bianchi, E., Perret, F., Rivasseau, A., Limpalaër, L., Monnier, E., Bouchet, P., 2014. When everything converges: 
Integrative taxonomy with shell, DNA and venomic data reveals Conus conco, a new species of cone snails (Gastropoda: Conoidea). Mol. Phylogenet. Evol. 80, 186-192. doi:10.1016/j.ympev.2014.06.024

Quoy, J.R.C., Gaimard, J.P., 1833. Voyage de découvertes de l’Astrolabe. Zoologie, Atlas. J. Tastu, Editeur-Imprimeur, Paris.

Richard, G., 1985. Conidae de Polynésie Française (III). Xenophora 28, 9-20.

Röckel, D., Korn, W., Kohn, A.J., 1995. Manual of the Living Conidae. Vol. I, IndoPacific. Christa Hemmen Verlag, Wiesbaden.

Tröndle, J., Cosel, R. v., 2005. Inventaire bibliographique des mollusques marins de l’archipel des Marquises (Polynésie Française). Atoll Res. Bull. 542, 267-340.

DOI of original article: 10.1016/j.ympev.2014.06.024

Corresponding author: Nicolas Puillandre, Museum National d'Histoire Naturelle, Departement Systematique et Evolution, ISyEB Institut (UMR 7205 CNRS/UPMC/MNHN/EPHE), 43, Rue Cuvier, 75231 Paris, France. Tel: +33 140793173

Corresponding author email: puillandre@mnhn.fr 